\title{
Yenidoğanlarda Basınç Ülseri Gelişimini Önlemeye Yönelik Hemşirelik Girişimleri
}

\section{Nursery Procedures to Avoid Pressure Ulcer in Newborns}

\author{
Çiğdem Sarı, Naime Altay
}

1 Gazi Üniversitesi, SBF, Hemşirelik Bölümü Ankara-Türkiye

öz

Basınç ülseri hastanede yatış süresini uzatan, mortalite ve morbidite riskini arttıran, enfeksiyon gibi çeşitli komplikasyonların gelişmesine neden olup yoğun tedavi gerektiren önemli bir sağlık sorunudur. Basınç ülseri gelişme riski tüm çocukluk dönemlerinde fazla olmasına rağmen özellikle yenidoğan döneminde epidermis ve dermis tabakasında görülen özellikler nedeniyle daha da artmaktadır. Basınç ülserlerinin tedavisi zor olmakla birlikte, gelişimine neden olan risk faktörlerinin belirlenip, ortadan kaldırılması ve etkili hemşirelik bakımıyla önlenebilir bir sorundur. Cilt bütünlüğü bozulması açısından riskli gruplar içerisinde yer alan yenidoğanlara bakım veren hemşirelere, basınç ülseri önleme konusunda önemli görevler düşmektedir. $\mathrm{Bu}$ makalenin amacı, yenidoğanlarda basınç ülserlerini önlemeye yönelik hemşirelik girişimlerine bir rehber oluşturmasıdır. Makalede yenidoğanlarda basınç ülserlerinin gelişim nedenleri, bölgeleri, basınç ülserini önlemenin önemi ve basınç ülseri gelişimini önlemeye yönelik hemşirelik girişimlerine yer verilmiştir.

Anahtar Kelimeler: Yenidoğan, basınç ülseri, önleme, hemşirelik girişimleri

\section{ABSTRACT}

Pressure ulcer is a significant health problem extending hospitalization duration at hospitals and increasing the risk of mortality and morbidity. Though risk of pressure ulcer development is high in all childhood periods, it rather increases due to differences in epidermis and dermis layer especially during neonatal period. No matter how difficult is treatment of pressure ulcer, it is a preventable problem through an effective nursery care by determining risk factors causing its development and removing them. Nurses taking care of newborns, being in risky group on grounds of disruption of skin integrity, have major responsibilities on avoiding pressure ulcer. Nursery procedures to avoid pressure ulcer involve risk evaluation along with determining newborns at risk, daily skin assessment, control of moisture, providing nutrition and hydration and decreasing pressure. The purpose of this study is to form guidance for nursery procedures to avoid pressure ulcer in newborns. The article includes the reasons of pressure ulcer development in newborns, its locals, importance of pressure ulcer avoidance and nursery procedures to avoid pressure ulcer development.

Keywords: newborn, pressure ulcer, avoidance, nursery procedures

Corresponding Author: Çiğdem Sarı

Address: Gazi Üniversitesi, SBF, Hemşirelik Bölümü. Turkey

Başvuru Tarihi/Received: Kabul Tarihi/Accepted:

29-12-2014 06-07-2015

E-mail: cigdemsarii@hotmail.com 


\section{Giriş}

Basınç ülseri, tek başına basınç, friksiyon ya da yırtılma ve basıncın bir arada sebep olduğu, genellikle kemik çıkıntıları üzerinde ortaya çıkan lokalize deri ve/veya deri altı doku hasarıdır (1). Basınç ülseri hastanede yatış süresini uzatan, mortalite ve morbidite riskini arttıran, enfeksiyon gibi çeşitli komplikasyonların gelişmesine neden olup yoğun tedavi gerektiren önemli bir sağlık sorunudur (2-6). Sağlık bakım sisteminde tedavi ve bakım gideri yüksek olan basınç ülserlerinin önlenmesinde, kaliteli bakım büyük önem taşır. Basınç ülseri hemşirelik bakım kalitesinin önemli göstergelerindendir ve hemşireler basınç ülserinin önlenmesi ve tedavisinden sorumludurlar (5).

Basınç ülseri her yaş döneminde görülebileceği gibi, çocukluk döneminde de sık görülen bir sağlık sorunudur (7,8).Yapılan araştırmalar bebek ve çocuklarda basınç ülserinin yaygın olduğunu göstermektedir. Bebeklerde ve çocuklarda basınç ülseri görülme sıklığı \%3 ile \%28 arasında değişmektedir (9-11). Fujii ve arkadaşlarının (2010) Japonya`da yedi yenidoğan yoğun bakım ünitesinde basınç ülseri görülme sıklığını araştırdıkları çalışmanın sonucunda yenidoğanlarda basınç ülseri insidansı \%16 olarak tespit edilmiştir (12).

Bebeklerde ve çocuklarda deri yapısının yetişkinden farklılıklar göstermesi deri bütünlüğünü etkileyen bir faktördür. Basınç ülseri gelişme riski tüm çocukluk dönemlerinde fazla olmasına rağmen $(6,7,11,13)$, yenidoğan döneminde bu risk daha da artmaktadır (9). Preterm ve term yenidoğanın epidermis ve dermis tabakalarında görülen farklııklar nedeniyle basınç ülseri gelişme riski daha fazladır $(14,15)$. Yenidoğan bebekler, epidermis ve dermis ince, vücut yüzey alanı geniş, ter

bezlerinin fonksiyonlarının tam gelişmemesi ve birçok sistemin immatür olması gibi özelliklerle yetişkinlerden ayrılırlar $(13,16$, 17). Böylelikle cilt hasarı ve infeksiyonlar daha sık, ilaçların toksititesi daha fazladır. Tüm bu özellikler yenidoğan döneminde basınç ülseri gelişme riskini arttırmaktadır (18).

Yenidoğanda basınç ülseri gelişmesi, bebeğin hastanede kalıs süresinin uzamasına, yoğun tedavi uygulanmasına, yenidoğan ebeveyn ayrılığının uzamasına, bebeğin ağrı yaşamasına ve enfeksiyon gibi çeşitli komplikasyonlara neden olmaktadır. Bu durum, hem yenidoğanların hem de ailelerinin yaşam kalitesini olumsuz etkilemektedir.

Basınç ülserinin gelişmesi bireyin yaşam kalitesini etkimekle birlikte sağlık çalışanlarının da iş yükünü arttırmaktadır (19). Bu da istenen bakım sonuçlarına ulaşmayı engellemekte ve sağlık bakım kuruluşuna önemli bir finansal yük getirmektedir. Ligresti ve Bo (2007) 'nun çalışmalarında belirttiği gibi italya'da her yıl yaklaşık 800.000 kişide basınç ülserleri gelişmektedir ve bu hastaların bakım ve tedavisi bu bölümlerde çalışan eğitilmiş hemşirelerin işteki etkinliklerinin \%60'ını almaktadır (20). Brem ve arkadaşlarının (2010), evre IV basınç ülserlerinin maliyetini araştırdıkları çalışma sonucunda mali yükün $124.327 \$-29.248$ \$ aralığında olduğu ortaya çıkmıştır ve bu bilgilere dayanarak $A B D$ 'de bası yarası tedavilerinin toplam maliyetinin yıllık 11000000000 \$ aştı̆̆ı tahmin edilmektedir (21). Ülkede mali yükü yüksek olan hastalıklar olarak kardiovasküler hastalıklardan sonra basınç ülserlerinin olması dikkat çekmektedir $(21,22)$.

Basınç ülserinin bireyin yaşam kalitesine olan etkileri ve getirdiği finansal yük düşünüldüŭünde basınç ülserinin önlenmesi önemli bir zorunluluktur. Amerikan Hemşireler birliği tarafından kurulan Hemşirelik Kalite Göstergeleri Ulusal Veri Tabanı komisyonu, 
2007 yılında hasta güvenliği hedeflerini yayınlamıştır. Bu hedeflerden biri de basınç ülseri gelişimini azaltmaktır. ABD'de Sağlık Hizmetleri Geliştirme Enstitüsü tarafından 2007 yılında "5 milyon Hayat" kampanyası başlatılmış ve kampanyanın ilk temel göstergesi pediatri alanındaki basınç ülserlerini önlemek şeklindedir $(23,24)$. Türkiye Cumhuriyeti Sağlık Bakanlığı, 01/03/2011 Tarihli ve 9489 sayılı Makam Onayı ile "Sağlıkta Performans ve Kalite Yönergesi" kapsamında yoğun bakım ünitelerindeki hastaların basınç ülseri oranlarının izlenmesi ve önleyici ve düzeltici faaliyet yapılması zorunluluk haline getirilmiştir (25).

Basınç ülseri gelişimini azaltılmasına yönelik yasal düzenlemeler ve sağlık hizmetleri ve bakım teknolojisindeki ilerlemelere rağmen, basınç ülseri halen devam eden bir sorundur. Basınç ülserlerinin tedavisi zordur, ancak gelişimine neden olan risk faktörlerinin belirlenip, ortadan kaldırılması ve etkili bir hemşirelik bakımı ile önlenebilir bir sorundur. Basınç ülserleri sağlık bakım sisteminde önemli kalite göstergelerinden biri olup, önlenmesi holistik bakım anlayışına sahip multidisipliner ekip ile sağlanabilir (26). Basınç ülserlerinin önlenmesi, holistik bakımı ilke edinmiş sağlık ekibinin önemli üyelerinden olan hemşireler için profesyonel bir sorumluluktur $(24,27)$. Basınç ülserlerini önlemenin en önemli iki aşaması; basınç ülseri gelişimine neden olan etkenlerin belirlenmesi ve bu etkenleri ortadan kaldırmaya yönelik uygun hemşirelik girişimlerinin uygulanması şeklindedir.

Cilt bütünlüğü bozulması açısından riskli gruplar içerisinde yer alan yenidoğanlara bakım veren hemşirelere, basınç ülseri önleme konusunda önemli görevler düşmektedir. Basınç ülseri gelişme riski olan yenidoğanlar için önlemeye yönelik hemşirelik bakımında amaç, yenidoğanın hastaneye kabul edilişinden itibaren risk değerlendirilmesi yapılması ve uygun önleme girişimlerinin planlanmasıdır. Bakımın etkinliği açııından doku hasarı oluşmadan koruyucu önlemlerin alınması büyük önem taşımaktadır.

Hemşirelerin, yenidoğanlarda basınç ülserinin önlenmesinde, belirlenmesinde ve girişimlerin erken dönemde uygulanmasında önemli işlevleri bulunmaktadır. Bu makalenin amacı, yenidoğanlarda basınç ülserlerini önlemeye yönelik hemşirelik girişimlerine bir rehber oluşturmasıdır. Makalede yenidoğanlarda basınç ülserlerinin gelişim nedenleri, bölgeleri, basınç ülserini önlemenin önemi ve basınç ülseri gelişimini önlemeye yönelik hemşirelik girişimlerine yer verilmiştir.

\section{Yenidoğanda Basınç Ülserini Önlemeye} Yönelik Hemşirelik Girişimleri

Basınç ülserini önlemeye yönelik hemşirelik girişimlerini beş grup altında toplayabiliriz:

1. Risk değerlendirmesi ve risk altındaki yenidoğanların belirlenmesi,

2. Günlük cilt değerlendirmesi,

3. Nem kontrolünün yapılması,

4. Beslenme ve hidrasyonun sağlanması,

5. Basıncın azaltılması.

1. Risk Değerlendirmesi ve Risk Altındaki Yenidoğanların Belirlenmesi: Basınç ülseri gelişmesi yönünden riskli yenidoğanların belirlenebilmesi ve buna yönelik hemşirelik girişimlerinin planlanabilmesi için öncelikle basınç ülserine neden olan faktörlerin bilinmesi gerekmektedir. Yenidoğanlarda basınç ülseri gelişimine neden olabilecek risk faktörleri Tablo 1'de verilmiştir (28-37).

Yenidoğanlarda basınç ülseri gelişimine neden olan risk faktörlerinin belirlenmesinde uygulanan en önemli girişimlerden biri geçerli ve güvenilir bir risk değerlendirme ölçeği kullanılmasıdır $\quad(26,38-40)$. Literatür 
incelendiğinde yenidoğanlarda cilt risk değerlendirmesi için en sık kullanılan ölçekler; Neonatal/Infant Braden Q Scale ve Neonatal Skin Risk Assessment Scale' (Yenidoğan Cilt Risk Değerlendirme Ölçeği') dir.

Neonatal/Infant Braden Q Ölçeği, 1996 yılında Quigley ve Curley tarafından Braden Ölçeğinden yararlanılarak uyarlanmıştır. Ölçek hareketlilik, aktivite, duyusal algılama, sürtünme-yırtılma, nem, beslenme ve doku perfüzyonu olmak üzere yedi alt ölçekten oluşmuştur. Ölçek neonatallere göre modifiye edilmiş ancak, geçerlilik ve güvenirlik çalışması yapılmamıştır (41).

Yenidoğan Cilt Risk Değerlendirme Ölçeği, 1997 yılında Huffines ve Logsdon tarafından Braden Ölçeği model alınarak geliştirilmiştir. Braden Ölçeğine benzer olarak yenidoğan popülasyonuna ait 6 parametreden oluşmuştur ve gestasyon yaşına göre düzenlenmiştir. Bunlar genel fiziksel durum, mental durum, hareketlilik, aktivite, beslenme, nemdir. Ölçekte her bir parametre birden dörde kadar puanlanmaktadır. Ölçekten alınabilecek puan altı ile yirmi dört arasında değişmektedir. Ölçekten alınan puanın yüksek olması yenidoğanın cilt bütünlüğünde bozulma riskinin arttığını gösterirken, puanın düşük olması cilt bütünlüğü bozulma riskinin düşük olduğu anlamına gelmektedir $(29,34)$.

Huffines ve Logsdon (1997) tarafından yapılan Yenidoğan Cilt Risk Değerlendirme Ölçeği'nin geçerlik ve güvenirlik çalışmasında ölçeğin sensitivitesi \%83, spesifitesi ise \%81 olarak bulunmuştur. Görüşmeciler arası güvenirlik \%97 olarak belirlenmiştir (42). Ülkemizde de Sarı ve Altay (2014) tarafından Yenidoğan Cilt Risk Değerlendirme Ölçeğinin (NSRAS) geçerlik ve güvenirlik çalışması yapılmıştır (43).

2. Günlük Cilt Değerlendirmesi: Basınç ülserlerini önlemeye yönelik hemşirelik girişimlerinden biri de günlük cilt değerlendirmesinin yapılmasıdır. Yenidoğan kliniğe kabul edildiğinde, deri bastan ayağa ve daha sonra deri bütünlüğünün bozulma olasılığı olduğu bölgeler, özellikle kemik çıkıntıları renk değişikliği yönünden her gün dikkatle gözlenmelidir. Herhangi bir doku hasarı varsa eritemde artma, ödem, pürülan, eksuda, ağrı ve ısıda artma gibi enfeksiyon belirtileri değerlendirilmelidir. Ayrıca doku hasarının derinlik ve iyileşme belirtilerinin de değerlendirilmesi büyük önem taşır (44). Ayello ve Lyder (2008), tüm vücutta özelliklede basıncın yoğun olduğu bölgelerde deri bütünlüğünde bozulma belirtilerinin sık olarak gözlemlenmesi gerektiğini belirtmişlerdir (45).

Yenidoğanlara uygun bir cilt değerlendirme aracının kullanılması verilerin objektifliği açısından yarar sağlayacaktır. Bu anlamda, yenidoğanlarda günlük cilt değerlendirmesi yapmak için yaygın olarak kullanılan ölçek ise Neonatal Skin Condition Score (Yenidoğan Cilt Durum Skoru)'dur. Neonatal Skin Condition Score (Yenidoğan Cilt Durum Skoru) kuruluk, eritem ve cilt bozulması olmak üzere 3 parametreden oluşmuş olup, yenidoğanların cilt durumlarıyla ilgili objektif veri sağlayarak müdahale edilmesi gereken yenidoğanları belirlemede kullanılan bir ölçektir (33). Cilt değerlendirmesi yapıldıktan sonra, değerlendirme çıktılarının kaydı da büyük önem taşır. Bu çıktılara göre uygun hemşirelik girişimleri planlanmalıdır.

3. Nem Kontrolünün Yapılması: Yenidoğanın kuru kalmasını sağlama ve cildin nemlendirilmesi.

Basınç ülserlerinin gelişmesinde rol oynayan risk faktörlerinden biri de nemdir. Nem, ciltte her türlü döküntünün gelişmesine olanak verecek şekilde derinin yumuşamasına neden olur. Basınca maruz kalan dokularda ülser gelişmesini kolaylaştırır (46). Ayrıca, derinin sürtünme, yırtılma gibi fiziksel faktörlere karşı direncini azaltarak basınç 
ülseri gelişimine katkıda bulunur. Cilt yapısı farklılıklarıyla basınç ülseri gelişme riski fazla olan yenidoğanlarda nem kontrolünün sağlanması ayrıca önem taşır. Deri üzerindeki nemlilik; termoregulasyonu sağlamada yetersizliğe bağıı olarak, nemlendirilmiş oksijen uygulaması nedeniyle ya da ortamdaki vücut sıvılarına bağlı olarak gelişebilir. Basınç ülseri gelişiminde nemin fazla olması kadar nemin azlığı da etkilidir. Yenidoğanlarda nem azlığı deri turgorunda azalmaya yol açmaktadır. Ayrıca ortamın nem oranındaki azalma, epidermis ve dermis tabakası hassas olan yenidoğanlarda mukozalarda kuruluk ve cilt bütünlüğü bozulma riskini arttırmaktadır.

Nem Kontrolünün Yapılmasına Yönelik Hemşirelik Girişimleri

* Her gün cilt risk değerlendirmesi yapılıp, neme neden olabilecek durumların belirlenmesi

* Cilt temizliği/bakımının rutin olarak yapılması

* Yenidoğanın cildi için en uygun, cilt kuruluğunu tahriş ve en aza indiren ürünlerin seçilmesi (Yenidoğanın deri $\mathrm{pH}^{\prime}$ । 6.4 civarındadır. Kullanılacak ürünlerin deri Ph`ına uygun olması gerekir. Gliserinli ve lanolinli ürünler kullanılabilir).

\footnotetext{
* Her bir yenidoğanın bireysel intiyacına ve nemin olduğu bölgeye göre gereksinimlerinin saptanıp, uygun girişimlerin planlanması
}

* Lezyonların en çok oksiput, anal, perianal alanlar, bilekler, dirsekler, eklemler ve çenede oluşması nedeniyle bu bölgelere koruyucu losyonlar sürülmesi

* Basınç ülseri gelişimini önlemek amacıyla masajın kullanılmaması $(22,47,48)$
Yenidoğanın deri bütünlüğünün korunması ve nem kontrolünün sağlanması için hemşireye bağımlıdırlar ve bu yüzden hemşirelik bakım planında hijyen önemli bir yer tutar.

\section{Beslenme ve Hidrasyon Sağlanması}

Bası yarası gelişmesi yönünden riskli gruplardan biri olan yenidoğanlarda, beslenme faktörlerinin ve hidrasyonun da değerlendirilmesi gerekmektedir. Prematüreliğe bağlı protein ve yağ gibi besin faktörlerinin azlığı veya alımında bozukluk, düşük doğum ağırlığı, düşük vücut ağırlığı, istenmeyen kilo kaybı ve dehidratasyon basınç ülserlerinin gelişimine katkıda bulunur $(22,47,48)$.

\section{Beslenme ve Hidrasyonun Sağlanmasına Yönelik Hemşirelik Girişimleri}

* Her yenidoğanın, beslenme durumu ve hidrasyonu bireysel olarak, değerlendirilmelidir.

* Yenidoğanların beslenme durumu değerlendirilirken, ağılık, boy, beden kitle indeksi, kol çevresi ölçümü gibi antropometrik ölçümler ile albümin, total protein, hemoglobin, hematokrit gibi biyokimyasal göstergeler dikkate alınmalıdır (49).

* Her bir yenidoğan için aldığı - çıkardığı takibi yapılmalıdır.

* Beslenme değerlendirilmesi, risk faktörlerini, protein, kalori ve vitamin ihtiyaçlarını ve hidrasyon durumunu kapsayacak şekilde olmalıdır.

* Yenidoğanın

gereksinimi doğrultusunda besin öğelerini ve sıvı alımını sağlayacak uygun beslenme şekli saptanmalıdır. 
Beslenme durumu ve hidrasyon değerlendirmelerinin kaydı yapılmalıdır.

\section{Basıncın Azaltılması}

Yenidoğan yoğun bakım ünitelerinde basıncı azaltmaya yönelik girişimler hemşirelik bakımında önemli bir yer tutar. Özellikle, durumu stabilolmayan, cerrahi ve invaziv girişimlere ihtiyacı olan, tıbbi cihazların yoğun olarak kullanıldığı yenidoğanlarda, basıncı azaltmaya yönelik uygulanacak hemşirelik girişimleri ayrıca önem taşır. Basıncı azaltmaya yönelik hemşirelik girişimleri üç grup altında ele alabilir.

Basıncı azaltmaya yönelik hemşirelik girişimleri

1. Tıbbi cihazların basısını azaltmaya yönelik girişimler

2. Pozisyon değişikliğinin sağlanması

3. Destek yüzeylerinin kullanılması

Hareketliliğin ve cilt duyarlılığın azalmasıyla birlikte yenidoğan yoğun bakımda kullanılan tıbbi cihazların varlığı basınç ülseri gelişme riskini arttırmaktadır. Yenidoğan yoğun bakım ünitelerinde özellikle ıntravenöz kateterler, pulseoksimetre probları, trakeostomiler, enteral ya da nazal tüpler gibi tıbbi cihazlar sıklıkla kullanılmaktadır ve bu cihazların kullanıldığı cilt alanlarının sıklıkla gözlenmesi gerekmektedir $(8,50,51)$. Willock ve arkadaşlarının (2005) basınç ülserlerinin \% 50 den fazlasının ekipman ve cihazlara bağı geliştiğini belirtmiştir (51). Tıbbi cihazlara ya da diğer risk faktörlerine bağlı olarak oluşan basınç ülserleri genelde yüzeyle temas halindeki vücudun geniş kısımlarında oluşur ve yenidoğanlarda basınç ülseri gelişmesi yönünden en büyük risk alanı oksipital bölgedir (52,53).

Yenidoğan yoğun bakım ünitelerinde sürekli ya da aralıklı infüzyon tedavisi alan yenidoğanlarda ıntravenöz katetere bağlı basınç ülseri gelişebilir. Bu nedenle ıntravenöz kateterlerin çevresindeki deri sıklıkla izlenmelidir. Mclane ve arkadaşları (2004) pediatri hastalarının \%15'inde ekstravazasyonun geliştiğini ve kateterizasyona bağlı gelişen flebit ve ekstravazasyonun cilt bütünlüğünü bozacağından dikkatli olunması gerektiğini ifade etmiştir (34). Yine pulseoksimetre probları basınç ülserine neden olan tıbbi cihazlardandır. Günlük kontrol edilmesi gereklidir. Probların değişimi kurumlara bağı olarak değişmekle beraber genellikle 2 saatte bir değiştirilmesi ve tıbbi cihazlar ile deri arasına basıncı azaltan köpük gibi materyallerin konulması yarar sağlayabilir (10). Fujioka ve arkadaşları (2008) düşük doğum ağırlıklı yenidoğanlarda endotrakeal tüp tespiti nedeniyle üst dudakta basınç ülserlerinin sık geliştiğini ifade etmişlerdir. Üst dudaktaki basınç ülseri gelişimini engellemek için esnek ince tabakalı yay gibi bir kemeri endotrakeal tüpe bağlı olacak şekilde üstten her iki yanağa doğru yerleştirip ve yapışkan bantlarla sabitlemenin etkili olacağı belirtilmiştir. Böylelikle endotrakeal tüpün tespiti daha iyi şekilde yapılmış ve bantlar çıkarıldığında ciltte fazla gerginlik ve tahriş olmayacaktır (54).

Basıncı azaltmaya yönelik ele alınacak diğer hemşirelik girişimleri de; pozisyon değişikliğinin sağlanması ve destek yüzeylerinin kullanılmasıdır. Basınç altındaki alanların korunması, hastaya pozisyon verilerek ya da dokuların yük yönetimi için tasarlanmış basıncı dağıtan özel cihazlar ile sağlanması mümkündür $(22,24,48)$. Pozisyon değişikliği ve destek yüzeylerinin kullanılması ile hassas bölgeler ya da basınç noktaları ile diğer alanlar arasında basıncın dağıtılması rahatlıkla sağlanabilir $(24,55)$.

Pozisyon değişikliğindeki amaç basınç ülseri yönünden riskli alanlardaki dolaşımın 
korunmasını sağlamak ve basıncın etkilerini hafifletmek ya da ortadan kaldırmaktır. Pozisyon değişikliğinin ne sıklıkta yapılacağı her bir yenidoğan için ayrı olarak planlanmalıdır. Yenidoğanlarda doku toleransı, mobilite düzeyi, tedavinin amaçları, tıbbi cihazların varlığı ve derinin durumuna göre pozisyonun ne sıklıkta değiştirileceği belirlenmelidir. Pozisyon değişikliğinde beklenen cevap gözlemlenmiyorsa, pozisyon değiştirmede kullanılan yöntem ve sıklığının gözden geçirilmesi gereklidir $(55,56)$.

Hastaya sık pozisyon vermenin sınırlamaları, beraberinde getirdiği zaman ve mali yükü düşünüldüğünde basınç ülserleri gelişimini önlemek için çeşitli destek yüzeyleri tasarlanmıştır. NPUAP'in tanımına göre destek yüzey: doku yükü, mikro-iklimlendirme veya her çeşit şilte, entegre yatak sistemi, şilte değişimi, örtü, oturma yastığı veya oturma yastığı örtüsü gibi terapötik fonksiyonların yönetimi için tasarlanmış basıncı tekrar düzenleyici özel cihazdır (24). Basınç giderici cihazların amacı hasta ile ara yüzey arasındaki sürtünme gibi basınç kuvvetlerinin süresi ve şiddetini azaltmaktır (57).

Bu cihazlar enerjiyle çalışıp çalışmama durumuna göre statik ya da dinamik cihazlar olarak adlandırılmaktadır. Statik cihazlar düşük teknolojili destek yüzeyleri olup, enerji olmadan çalışmaktadır ve vücudun geniş alanlarındaki basıncını dağıtmaktadırlar. Dinamik cihazlar ise; yüksek teknolojili destek yüzeyleri olmakla birlikte enerjiyle çalışmaktadırlar ( düşük hava kayıplı yataklar vb.) $(1,57,58)$. Kadın Sağlığı, Obstetrik ve Yenidoğan Hemşireliği Derneği (AWHONN) yenidoğanlarda koyun postu, yumuşak battaniyeler, su yatakları ya da bebek bezi gibi destek yüzeylerini önermişlerdir (47). Bazı araştırmacılar ise; jel yastıklar, koyun postu, basıncı azaltan şiltelerin yenidoğanlarda kullanılabileceğini belirtmişlerdir (29,41,5962). Özellikle bazı çalışmalar jel yastıkların yenidoğan gibi yüksek riskli hastalarda kullanımın etkin olduğunu açıklamıştır $(29,58$ 60). Literatüre bakıldığında destek yüzeylerinin yetişkin hastalardaki kullanımıyla ilgili çalışmaların olduğu görülürken pediatrik hastalarda ve özellikle yenidoğanlarda bu konuda sınırlı sayıda çalışma olması dikkat çekmektedir.

Turnage-Carrier ve arkadaşları (2008) yenidoğanlarda kullanılan çeşitli yatak yüzeylerinin ara yüz basınçlarının karşılaştırdıkları çalışmada köpüklü standart yatak şiltesi, köpüksüz yapıdaki şilte, jel şilte, su yastığı ve jel simit olmak üzere beş destek yüzeyi kullanmıştır. Köpük kaplamalı yüzeyde düşük basınç söz konusu iken, standart beşikte 100 mmHg gibi yüksek bir basınç oranı tespit edilmiştir. Standart bir yatak ile köpüklü ya da diğer destek yüzeyleri arasında önemli oranda basınç farkı olduğu sonucuna varılmıştır. Prematürelerde cilt yapısına uygun destek yüzeylerinin seçiminin oldukça önemli olduğu vurgulanmıştır (63).

Garcia- Molina ve arkadaşları (2012) pediatrik yoğun bakım ünitesinde kullanılan sürekli düşük basınçlı şilte sisteminin basınç ülseri insidansına olan etkisini araştırmışlar ve şilte sisteminin basınç ülserini önlemede olumlu etkileri olduğunu, özellikle pozisyon değişikliği yapılamayan hastalarda etkinliğinin fazla olduğunu belirtmişlerdir (61).

Yenidoğanlarda baş şekline uygun olarak daha kolay şekil alma, daha yuvarlak yapıya sahip olma ve cilt bütünlüğünü korumak açısından avantajlı yönleriyle sıklıkla kullanılan destek yüzeylerinden biri de jel dolgulu yastıklar ve pedlerdir (29). Bu yastıklar yenidoğanın başını sabitlemeyi en aza indirdiği ve herhangi bir kemik altına kolaylıkla yerleştirilebildiği için sıklıkla tavsiye edilmektedir. Bu ürünlerin diğer bir avantajıda basıncı azalmak için kullanılacak başka bir araca kullanım açısından kolaylık sağlamasıdır. 


\section{Sonuç}

Basınç yaralarının varlığı, yaşam kalitesini bozmakta, enfeksiyon ve ölüm sıklığının artmasının yanı sıra maddi kayıplara yol açmaktadır. Tüm yaş gruplarında olduğu gibi yenidoğanlarda da sık görülen ve etkili bir hemşirelik bakımıyla önlenebilir bir sorundur. Bası yarasının oluşumunu ve ilerlemesini önlemek, tedavi etmekten çok daha kolay ve ucuzdur. Sağlık profesyonellerinden olan hemşirelere basınç ülserine neden olan faktörlerin belirlenmesinde ve önlenmesinde önemli görevler düşmektedir. Bu makalede de yenidoğanlarda basınç ülseri gelişimini önlemeye yönelik hemşirelik girişimlerine yer verilmiştir.

\section{Tablo 1: Yenidoğanlarda basınç ülseri gelişimine neden olan risk faktörleri}

\begin{tabular}{|c|c|}
\hline Risk faktörleri & Görülme nedenleri \\
\hline \multicolumn{2}{|l|}{ Basınç toleransı } \\
\hline Hareket kısıtlılığı & $\begin{array}{l}\text { Yenidoğanın nöromüsküler gelişiminin tamamlanmamış olması bazı uyaranlara karşı (basınç vb.) tepki } \\
\text { vermesini etkiler. }\end{array}$ \\
\hline Azalmış aktivite & $\begin{array}{l}\text { Yenidoğanlarda vücut pozisyonunu değiştirme sıklığının azalması; hastalığın şiddeti, azalmış kas tonusu, } \\
\text { mekanik ya da farmakolojik yöntemlere bağlı olarak gelişebilir. Yenidoğan yoğun bakım ünitelerinde genellikle } \\
\text { yenidoğanların tıbbi cihazlara bağlı olması aktivitelerinin azalmasına yol açabilmektedir. }\end{array}$ \\
\hline Duyusal algılamada azalma & $\begin{array}{l}\text { Yenidoğanların duyusal algılarında bir sorun olmasa bile; hastalığın şiddeti, nöromüsküler hastalıklar ya da } \\
\text { farmakolojik faktörlerin etkisiyle duyusal algı sınırlanabilir. İrritabilite nedeniyle yenidoğanlar basınca yanıt } \\
\text { vermede sınırlı beceriye sahip olabilirler. }\end{array}$ \\
\hline \multicolumn{2}{|l|}{ Doku toleransı } \\
\hline Değişmiş doku perfüzyonu & $\begin{array}{l}\text { Yenidoğanlarda prematüreliğe ya da hastalığa bağlı olarak gaz değişiminde problem olabilmektedir. Bu durum } \\
\text { yenidoğanda doku perfüzyonunun bozulmasına yol açabilir. }\end{array}$ \\
\hline Beslenme durumu & $\begin{array}{l}\text { Prematürelerde yağ, protein eksikliği ve çinko gibi minerallerin azlığı, basınç ülseri gelişimine neden olabilir. } \\
\text { Ayrıca hastalıklara ve prematüreliğe bağlı yetersiz beslenme nedeniyle de basınç ülseri gelişebilir. Yetersiz } \\
\text { beslenme, kilo kaybına beraberinde doku kütlesinin azalmasına ve kaslarda zayıflığa neden olarak basınç ülseri } \\
\text { gelişme riskini arttırmaktadır. }\end{array}$ \\
\hline Cilt IsıSı & $\begin{array}{l}\text { Yenidoğanın ısı stabilitesi, sıcak ya da soğuk stresi, oksijen tüketimindeki artma ve artmış solunum sıkıntısı gibi } \\
\text { sebeplere bağı ılarak değişebilir. Hastalık ya da ortamın ısısı gibi faktörlerinde etkisiyle ısı stabilitesindeki } \\
\text { değişim, vücutta sıvı elektrolit dengesizliğine ve dolaşımın bozulmasına yol açarak basınç ülseri gelişme riskini } \\
\text { arttırmaktadır. }\end{array}$ \\
\hline Cilt nemliliği & $\begin{array}{l}\text { Vücut sıvıları (idrar, dışkı ve yara akıntısı), terleme, oksijen uygulaması gibi faktörlere bağlı olarak cilt üzerinde } \\
\text { nemlilik oluşmaktadır. Nem fazlalığı epidermis tabakasının esnekliğini değiştirmektedir. Basınç ülseri } \\
\text { gelişiminde nemin fazla olması kadar nemin azlığı da bir risk faktörüdür. Yenidoğanlarda nem azlığı deri } \\
\text { turgorunda azalmaya yol açmaktadır. Ayrıca ortamın nem oranındaki azalma, epidermis ve dermis tabakası } \\
\text { hassas olan yenidoğanlarda mukozalarda kuruluk ve cilt bütünlüğü bozulma riskini arttırmaktadır. }\end{array}$ \\
\hline Sürtünme-Yırtılma & $\begin{array}{l}\text { Sürtünme cilt üzerinde bir objenin ya da cildin başka bir yüzeyle teması sonucu gerçekleşen mekanik bir } \\
\text { kuvvettir. Yenidoğanlarda da deriye tıbbi malzemelerin (oro- nazogastrik tüpler, kateterler, entübasyon } \\
\text { tüpleri, flasterler vb.) basısı ya da sürtünmesi, hareketliliğin azalması ve pozisyon değişikliklerinin yapılmadığı } \\
\text { durumlarda sürtünme - yırtılmaya bağlı basınçülseri gelişme riski artmaktadır. Yenidoğanın küvöz/yatak/kot } \\
\text { içerisinde pozisyon değişikliği ya da bakım esnasında oluşan sürtünme de epidermis üzerinde mekanik etki } \\
\text { yaratarak basınç ülseri gelişsimine neden olabilmektedir. }\end{array}$ \\
\hline Yaş & Yenidoğanların gestasyon yaşı azaldıkça cilt yapısının frajilliği ve basınç ülseri gelişme riski artmaktadır. \\
\hline
\end{tabular}

\section{KAYNAKLAR}

1. European Pressure Ulcer Advisory Panel and National Pressure Ulcer Advisory Panel. Prevention and treatment of pressure ulcers: quick reference guide. Washington DC: National Pressure Ulcer Advisory Panel; 2009.

2. Chan W, Pang S, Kwong E. Assessing predictive validity of the modified Braden scale for prediction of pressure ulcer risk of orthopaedic patients in an acute care setting. J Clin Nurs 2009;18:1565-1573.

3. Karaböcüoğlu M. Çocuk Yoğun Bakım. 1. Baskı. İstanbul Medikal Yayıncılık: İstanbul; 2008.

4. McCord S, McElvain V, Sachdeva R, Schwartz $P$, Jefferson LS. Risk factors associated with pressure ulcers in the pediatric intensive care unit. J Wound Ostomy Continence Nurs 2004:31:179-83.

5. Van den Heede K, Clarke SP, Sermeus W, Vleugels A, Aiken LH. International experts' perspectives on the state of the nurse staffing and patient outcomes literature. J Nurs Scholarship 2007;39(4):290-297.

6. Willock J, Baharestani MM, Anthony D. The development of the Glamorgan paediatric pressure ulcer risk assessment scale. J Wound Care.2009;18(1):17-21.

7. NoonanC, Quigley S, Curley MA. Using the Braden Q Scale to Predict Pressure Ulcer Risk in Pediatric Patients. J Pediatr Nurs. 2011;26:566-575.

8. Willock J, Maylor M. Pressure ulcers in infants and children. Nurs Stand 2004; 18(24):56-62. 
9. Suddaby EC, Barnett S, Facteau L. Skin breakdown in acute care pediatrics. Pediatr Nurs. 2005;31(2):132-148.

10. NoonanC, Quigley S, Curley MA. Skin integrity in hospitalized infants and children: a prevalence survey. J Pediatr Nurs. 2006; 21(6):445-453.

11. Schlüer $A B$, Cignacco $E$, Müller $M$, Halfens RJ. The prevalence of pressure ulcers in four paediatric institutions. J Clin Nurs 2009;18(23): 3244-3252.

12. Fujii K, Sugama J, Okuwa M, Sanada $H$, MizokamiY.Incidence and risk factors of pressure ulcers in seven neonatal intensive care units in Japan: a multisite prospective cohort study. Int Wound J 2010;7(5):323-328.

13. Schindler CA, Mikhailov TA, Fischer K, Lukasiewicz G, Kuhn EM, Duncan L. Skin integrity in critically ill and injured children. Am J Crit Care 2007;16(6):568-574.

14. Pasek TA, Geyser A, Sidoni M et al. Skin care team in the pediatric intensive care unit: A model for excellence. Crit Care Nurse 2008;28(2):125-135.

15. Törüner $E$, Büyükgönenç L, Altay N. Çocuklarda Basınç Ülserleri. Dokuz Eylül Üniversitesi Hemşirelik Yüksekokulu Elektronik Dergisi 2011;4:182-188.

16. Dağoğlu T, Ovalı F. Neonataloji. 2. Baskı. Nobel Tıp Kitapevi: İstanbul;2007.

17. Marcellus L. Determination of positional skin-surface pressures in premature infants. Neonatal Netw 2004;23(1):2530.

18. Verger JT, Lebet RM. AACN Procedure Manual for Pediatric Acute and Critical Care. 2 nd ed. St Louis, MO: Saunders Elsevier; 2008.

19. Akyol AD. Intervention Studies for Prevention of Ulcer in Turkey: A Literature Review. Int Nurs Rev 2006; 53: 308316.

20. Ligresti C, Bo F. Wound Bed Preparation of Difficult Wounds: An Evolution of the Principles of Tıme. Int Wound J 2007; 4(1): 21-29.

21. Brem H, Maggi J, Nierman D. High cost of stage IV pressure ulcers. Am J Surg 2010; 200(4):473-7.

22. Reddy M, Gill SS, Rochon PA. Preventing pressure ulcers: A systematic review. JAMA 2006;296(8):974.

23. McCannon CJ, Hackbarth AD, Griffin FA. Miles togo: An introduction to the 5 million lives campaign. Jt Comm J Qual Patient Saf. 2007;33(8):477-484.

24. National Pressure Ulcer Advisory Panel. Pressure ulcer definition.(2007). Available from: http://www.npuap.org/pr2.htm/15.09.2014.

25. Hastane Hizmet Kalite Standartları. İndikatör Yönetimi (2011). Available from: http://www.performans.saglik.gov.tr/index.php?lang=tr\&page= 46\&newsCat=1\&newsID=586/ 15.09.2014.

26. Karadağ A. Basınç Ülserleri: Değerlendirme, önleme ve tedavi. Cumhuriyet Üniversitesi Hemşirelik Yüksekokulu Dergisi 2003;7(2):41-47.

27. Uzun Ö, Tan MA. Prospective, Descriptive Pressure Ulcer Risk Factors and Prevalence Study at a University Hospital in Turkey. Ostomy Wound Manage 2007;53(2):44-56.

28. Australian Wound Management Association. Pan Pacific Clinical Practice Guideline for the Prevention and Management of Pressure Injury. Osborne Park: AustralianWound Management Association, Cambridge Media; 2012

29. Baharestani MM, Ratliff CR. Pressure ulcers in neonates and children: an NPUAP white paper. Adv Skin Wound Care. 2007; 20(4): 208-220.

30. Irshintago A, Sekine T, Suzuki K. Changes in skin and subcutaneous perfusion in very-low-birth-weight infantsduring the transitional period. Neonatalogy. 2011;100:162-168.

31. Irving V, Bethell E, Burton F. Neonatal wound care: minimizing trauma and pain. Wounds UK 2006;2:33-41.
32. Lund $\mathrm{CH}$, Kuller J, Lane AT, Lott JW, Raines DA. Neonatal skin care: the scientific basis for practice. J Obstet Gynecol Neonatal Nurs 1999;28(3):241-254.

33. Lund $\mathrm{CH}$, Osborne JW. Validity and reliability of the neonatal skin conditio nscore. J Obstet Gynecol Neonatal Nurs 2 004;33(3):320-327.

34. McLane KM, Bookout K, McCord S, McCain J, Jefferson LS. The 2003 National pediatric pressure ulcer and skin breakdown prevalence survey: a multisite study. J Wound Ostomy Continence Nurs 2004;31(4):168-178.

35. Razmus I, Lewis L, Wilson D. Pressure ulcer development in infants: state of the science. J. Healthc. Qual 2008;30:36-42.

36. Squires AJ, Hyndman M. Prevention of nasal injuries secondary to NCPAP application in the ELBW infant. Neonatal. Netw. 2009;28(1):13-27.

37. Waterlow J. Pressure sores in children: risk assessment. Paediatric Nursing 1998;10(4): 22-23.

38. Ayello EA, Baranoski $\mathrm{S}$, Lyder $\mathrm{CH}$, Cudigan, "Pressure ulcers". Baranoski S, Ayello EA, eds. Wound Care Essentials: Practice Principles. 1st Edition. Philadelphia: Lipincott Williams and Wilkins; 2004. p. 240-270.

39. McCaskey M, Kirk L, Gerdes C. Preventing skin breakdown in the immobile child in the home care setting. Home Healthc Nurse 2011;29(4): 248-255.

40. Perry AG, Potter PA. Clinical Nursing Skills \&Techniques. 6th ed. Mosby: USA;2006.

41. Quigley $S$, Curley M. Skin integrity in the pediatric population; preventing and managing pressure ulcers. J Soc Pediatr. Nurs 1996;1:7-18.

42. Huffines B, Logsdon MC. The neonatal skin risk assessment scale for predicting skin breakdown in neonates. Issues Compr Pediatr Nurs1997;20:103-114.

43. Sarı Ç, Altay N. (2014). Yenidoğan cilt risk değerlendirme ölçeğinin Türkçe geçerlik ve güvenirlik çalışması (Yayınlanmamış yüksek lisans tezi). Gazi Üniversitesi, Ankara.

44. Hockenberry MJ, Wilson D. Wong's Essentials of Pediatric Nursing. 9th ed. Elsevier-Mosby: Missouri; 2011.

45. Ayello $\mathrm{E}$, Lyder $\mathrm{CH}$. A new era of pressure ulcer account ability in acute care. Adv Skin Wound Care2008;21:13440

46. Walton-Geer, P. "Prevention of pressure ulcers in the surgical patient", AORN Journal 2009;89(3):538-548.

47. Association of Women'sHealth, Obstetrics and neonatal Nurses (AWHONN) \& National Association of Neonatal Nurses (NANN). Evidenced-Based Clinical Practice Guideline: Neonatal Skin Care. Washington, DC: AWHONN; 2001.

48. Gibbons W, Shanks HT, Kleinhelter P, Jones P. Eliminating facility acquired pressure ulcers at Ascension Health. Jt Comm J Qual Patient Saf 2006;32:488-496.

49. Prentice J. "Pressure ulcers". Templeton S, eds. Wound Care Nursing: A Guide to Practice. Ausmed Publications: Melbourne-Seattle; 2005.p.189-209.

50. Curley MAQ, Quigley SM, Lin M. Pressure ulcers in pediatric intensive care: incidence and associated factors. Pediatr Crit Care Med 2003;4(3):284-290.

51. Willock J, Harris C, Harrison J, Poole C. Identifying the characteristics of children with pressure ulcers. Nurs Times 2005;101:40-43.

52. Ball JW, Bindler RC. Child Health Nursing: Partnering with Children and Families.Upper Saddle River: New Jersey; 2006.

53. Kottner J, Wilborn D, Dassen T.Frequency of pressure ulcers in the paediatric population: A literature review and new empirical data. Int J Nurs Stud 2010;47:1330-1340. 
54. Fujioka M, Oka K, Kitamura R, Yakabe A. Upper lip pressure ulcers in very low birth weight infants due to fixation of the endotracheal tube. J Neonatal Nurs 2008;14(6): 207-210.

55. National Pressure Ulcer Advisory Panel, \& European Pressure Ulcer Advisory Panel. International review: Pressure ulcer prevention. Pressure, shear, friction and microclimate in context. A consensus document. London: Wounds International; 2010.

56. National Institue forHealth and Care Excellence. Pressure ulcers: prevention and management of pressure ulcers. London: NICE clinical guideline (179); 2014. ISBN: 978-14731-0525-6, Available from: http://www.nice.org.uk/guidance/cg179/resources/guidancepressure-ulcers-prevention-and-management-of-pressureulcers-pdf,15.11.2014.

57. McInnes E, Dumville JC, Jammali-Blasi A, Bell-Syer SE. Support surfaces for treating pressure ulcers.Cochrane Database Syst Rev 2011;12 [DOI:10.1002/14651858.CD009490].

58. McInnes E, Cullum NA, Bell-Syer SEM, Dumville JC, Jammali-Blasi A. Support surfaces for pressure ulcer prevention. Cochrane Database Syst Rev2010; 4 [DOI: 10.1002/14651858.CD001735.pub3].

59. Bernabe KQ. Pressure ulcers in the pediatric patient. Curr Opin Pediatr 2012;24:352-356.

60. Butler CT. Pediatric skin care: guidelines for assessment, prevention, and treatment. Pediatr Nurs 2006;32(5):443-450.

61. García-Molina P, Balaguer-López, E, Torra i Bou JE, Alvarez-Ordiales A, Quesada-Ramos C, Verdú-Soriano J.A. prospective, longitudinal study to assess use of continuous and reactive low-pressure mattreses to reduce pressure ulcer incidence in a pediatric intensive care unit. Ostomy Wound Manag 2012;58(7):32-39.

62. Kuller JM. Skin breakdown: risk factors, prevention, and treatment. Newborn Infant Nurs Rev 2001;1(1):35-42.

63. Turnage-Carrier C, McLane KM, Gregurich MA. Interface Pressure Comparison of Healthy Premature Infants with Various Neonatal Bed Surfaces. Adv Neonatal Care 2008;8:176-184. 